\title{
The trouble with minimum parking requirements
}

\author{
Donald C. Shoup * \\ Department of Urban Planning, University of California, Los Angeles, CA 90095-1656, USA
}

\begin{abstract}
Urban planners typically set the minimum parking requirements for every land use to satisfy the peak demand for free parking. As a result, parking is free for $99 \%$ of automobile trips in the United States. Minimum parking requirements increase the supply and reduce the price - but not the cost - of parking. They bundle the cost of parking spaces into the cost of development, and thereby increase the prices of all the goods and services sold at the sites that offer free parking. Cars have many external costs, but the external cost of parking in cities may be greater than all the other external costs combined. To prevent spillover, cities could price on-street parking rather than require off-street parking. Compared with minimum parking requirements, market prices can allocate parking spaces fairly and efficiently. (C) 1999 Elsevier Science Ltd. All rights reserved.
\end{abstract}

How can a conceptual scheme that one generation admiringly describes as subtle, flexible, and complex become for a later generation merely obscure, ambiguous, and cumbersome?

Thomas Kuhn

Urban planners set minimum parking requirements for every land use. These requirements typically ensure that developers will provide enough spaces to satisfy the peak demand for free parking. This article examines: (1) how urban planners set parking requirements, (2) how much the required parking costs, and (3) how parking requirements distort the markets for transportation and land. As a way to eliminate this distortion, I will propose that cities should price onstreet parking rather than require off-street parking.

\section{The shaky foundation of minimum parking requirements}

Where do minimum parking requirements come from? No one knows. The "bible" of land use planning, F. Stuart Chapin's Urban Land Use Planning, does not mention parking requirements in

\footnotetext{
${ }^{*}$ Tel.: +1-310-825-5705; fax: +1-310-206-5566; e-mail: shoup@ucla.edu
} 


\begin{tabular}{|c|c|c|}
\hline Asylum & Indoor Soccer Facility & Rifle Range \\
\hline Bingo Parlor & Junkyard & Slaughterhouse \\
\hline Convent & Kennel & Taxi Stand \\
\hline Diet Clinic & Landfill & Ultra-Light Flight Park \\
\hline Exterminator & Massage Parlor & Veterinarian \\
\hline Fraternity & Night Club & Wastewater Treatment \\
\hline Gunsmith & Oil Change Shop & Zoo \\
\hline Horse Stable & Pet Cemetery & \\
\hline
\end{tabular}

Fig. 1. Selected land uses with minimum parking requirements.

any of its four editions. ${ }^{1}$ The leading textbooks on urban transportation planning also do not mention parking requirements. ${ }^{2}$ This silence suggests that planning academics have not seriously considered - or even noticed - the topic.

This academic neglect has not prevented practicing planners from setting parking requirements for every conceivable land use. Fig. 1 shows a small selection of the myriad land uses for which planners have set specific parking requirements. Without training or research, urban planners know exactly how many parking spaces to require for bingo parlors, junkyards, pet cemeteries, rifle ranges, slaughterhouses, and every other land use.

Richard Willson (1996) surveyed planning directors in 144 cities to learn how they set parking requirements. The two most frequently cited methods were "survey nearby cities" and "consult Institute of Transportation Engineers (ITE) handbooks". Both strategies cause serious problems.

\subsection{Survey nearby cities}

Although surveying nearby cities seems a sensible way to set parking requirements, the Planning Advisory Service (1971), pp. 1-3) explains a serious problem with this approach:

Since the establishment of the principle that zoning ordinances may legally require the provision of off-street parking, ordinance drafters have been asking questions like: "How many spaces should be provided for a drive-in restaurant?" - or any other land use for that matter. The question is typically answered by relying upon what ordinances for other jurisdictions require... The implicit assumption is that other areas must know what they are doing (the ordinances were adopted, after all) and so it is a relatively safe bet to adopt a parking standard "close to the average". This may simply result in a repetition of someone else's mistakes. Nevertheless, the planner who needs to present a numerical standard by the next planning commission meeting cannot answer the original question by saying, "I don't really know" (italics added).

Setting parking requirements by relying on what other cities require not only risks repeating someone else's mistakes, but also fails to reveal where the requirements came from in the first place.

\footnotetext{
${ }^{1}$ See Chapin $(1957,1965)$, Chapin and Kaiser (1979) and Kaiser et al. (1995).

2 See Dickey (1983), Hanson (1995), Meyer and Miller (1984) and Papacostas and Prevedouros (1993).
} 


\subsection{Consult ITE handbooks}

To base parking requirements on more objective data, planners consult Parking Generation, published by the Institute of Transportation Engineers. For each land use, this publication reports the "parking generation rate", defined as the peak parking occupancy observed in surveys by transportation engineers.

A vast majority of the data... is derived from suburban developments with little or no significant transit ridership... The ideal site for obtaining reliable parking generation data would... contain ample, convenient parking facilities for the exclusive use of the traffic generated by the site... The objective of the survey is to count the number of vehicles parked at the time of peak parking demand (Institute of Transportation Engineers, 1987a, vii-xv, italics added).

The ITE summarizes the survey results and reports the average peak parking occupancy observed at each land use as the parking generation rate for that land use. Half of the 101 reported parking generation rates are based on four or fewer surveys of parking occupancy, and $22 \%$ of the parking generation rates are based on a single survey.

Because parking is free for $99 \%$ of all automobile trips in the United States, parking must be free at most of the ITE survey sites. ${ }^{3}$ Parking generation rates therefore typically measure the peak demand for parking observed in a few surveys conducted at suburban sites that offer ample free parking and lack public transit. Urban planners who use these parking generation rates to set minimum parking requirements are making a big mistake.

Parking Generation is a questionable resource for several reasons. First, parking generation rates are inflated by the ample free parking. Second, no information is provided on several key issues. Why and where were the surveys conducted? How long did the surveys last? How long did the peak parking occupancy last? Finally, nothing is said about off-peak parking occupancy. Parking Generation raises more questions than it answers.

Fig. 2 shows the Parking Generation's report for one land use, fast-food restaurants. At the 18 survey sites parking generation ranges from 3.55 to 15.92 parking spaces per 1000 square feet of floor area. ${ }^{4}$ The $\mathrm{R}^{2}$ of 0.038 shows that the variation in floor area accounts for less than $4 \%$ of the variation in peak parking occupancy. Parking generation is essentially unrelated to floor area in the sample. Nevertheless, the average parking generation rate - normally interpreted as the relationship between parking demand and floor area for a land use - is reported as precisely 9.95 parking spaces per 1000 square feet of floor area.

Urban planners who consult ITE publications act like frightened natives before a powerful totem. For example, the median parking requirement for fast-food restaurants in the US is 10 spaces per 1000 square feet of floor area, the same as the ITE's average parking generation

\footnotetext{
${ }^{3}$ For all automobile trips made on the previous day, the 1990 Nationwide Personal Transportation Survey (NPTS) asked 48,000 respondents, "Did you pay for parking during any part of this trip"? Ninety-nine percent of the 56,733 responses to this question were "No".

4 Gross floor area is the building's total floor area, including cellars, basements, corridors, lobbies, stairways, elevators, and storage. Gross floor area is measured from the building's outside wall faces.
} 

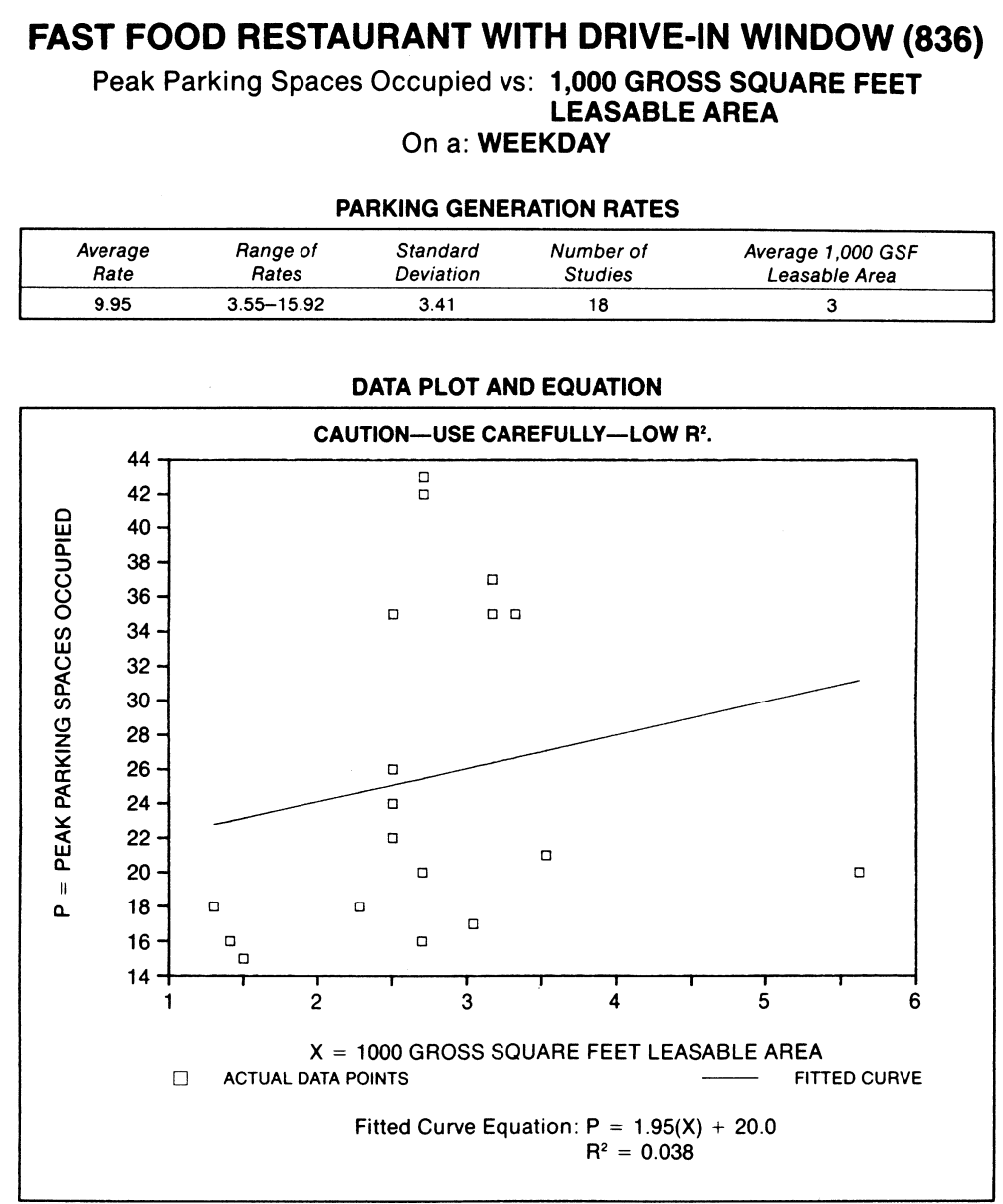

Fig. 2. Parking generation at fast food restaurants with drive-in windows. Source: Institute of Transportation Engineers (1987a, p. 146).

rate. ${ }^{5}$ Beyond the ITE's impressive professional reputation, the ITE data appeal to urban planners because minimum parking requirements are intended to meet the peak parking demand, and no one else provides systematic data that relate peak parking demand to land use.

\section{Minimum parking requirements inflate trip generation rates}

How do minimum parking requirements affect the demand for vehicle trips? The ITE publishes Trip Generation to show the demand for vehicle trips associated with various land uses. For each

\footnotetext{
${ }^{5}$ The Planning Advisory Service (1991) surveyed the parking requirements in 127 cities. The median of 10 spaces per 1000 square feet is for the cities that base their requirements on gross floor area.
} 
land use, this publication reports the "trip generation rate", defined as the number of vehicle trips that begin or end at a land use during a given period. In choosing a survey site the Institute of Transportation Engineers (1987b), p. 23) recommends, "the site should be self-contained with adequate parking not shared by other activities".

Half of the 1533 reported trip generation rates are based on four or fewer surveys, and $26 \%$ of the trip generation rates are based on a single survey. As with Parking Generation, the survey sites probably offer free parking. The trip generation rates therefore typically measure the number of automobile trips observed in a few surveys conducted at sites with free parking. Free parking inflates the trip generation rates because vehicle trip demand is higher where the price of parking is lower.

Fig. 3 shows Trip Generation's report for fast-food restaurants. It shows the total number of vehicle trips to and from each survey site during a 24-h period from Monday to Friday. Trip

\section{FAST FOOD RESTAURANT WITH DRIVE-THROUGH WINDOW (834)}

Average Vehicle Trip Ends vs: 1,000 SQUARE FEET GROSS FLOOR AREA On a: WEEKDAY

TRIP GENERATION RATES

\begin{tabular}{|ccccc|}
\hline \multicolumn{5}{|c|}{ Average Weekday Vehicle Trip Ends per } \\
\hline $\begin{array}{c}\text { 1,000 Square Feet Gross Floor Area } \\
\text { Trip Rate }\end{array}$ & $\begin{array}{c}\text { Range of } \\
\text { Rates }\end{array}$ & $\begin{array}{c}\text { Standard } \\
\text { Deviation }\end{array}$ & $\begin{array}{c}\text { Number of } \\
\text { Studies }\end{array}$ & $\begin{array}{c}\text { Average 1,000 } \\
\text { Square Feet GFA }\end{array}$ \\
\hline 632.125 & $284.000-1359.500$ & $*$ & 8 & 3.0 \\
\hline
\end{tabular}

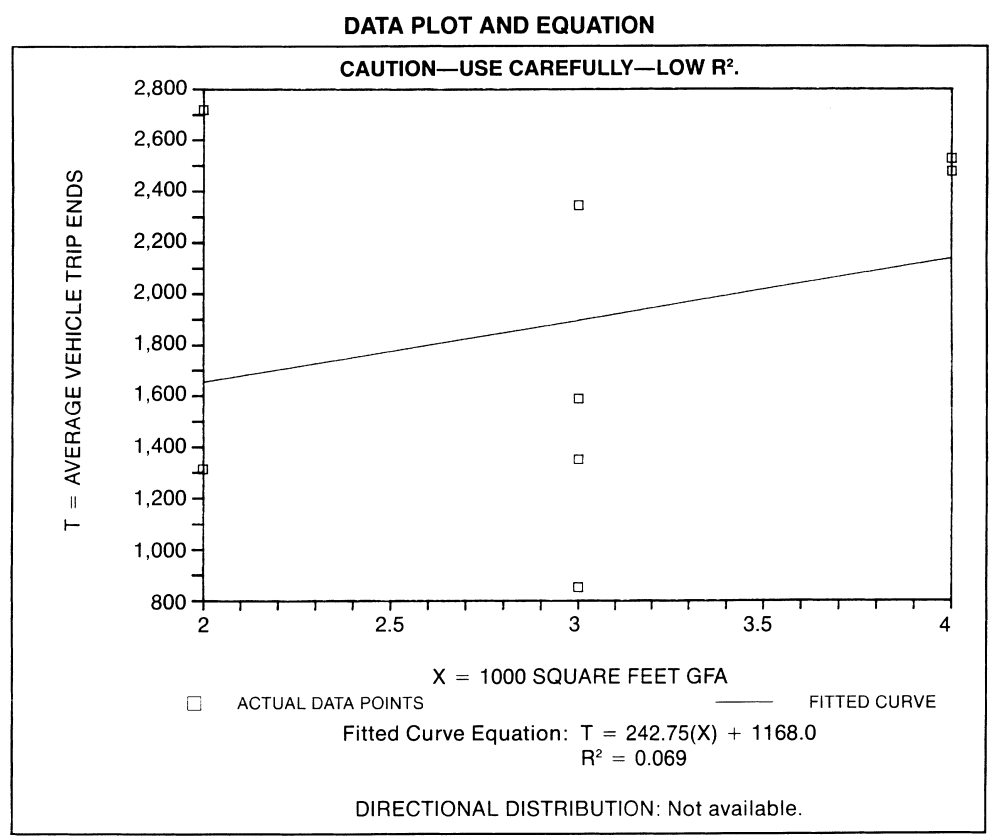

Fig. 3. Trip generation at fast food restaurants with drive-through windows. Source: Institute of Transportation Engineers (1987b, p. 1119). 
generation ranges from 284 to $1,359.5$ vehicle trips per day per 1000 square feet of floor area among the eight survey sites. The $\mathrm{R}^{2}$ of 0.069 shows that the variation in floor area accounts for less than $7 \%$ of the variation in vehicle trips. Trip generation is essentially unrelated to floor area in the sample. Nevertheless, the average trip generation rate - normally interpreted as the relationship between vehicle trips and floor area for a land use - is reported as precisely 632.125 vehicle trips per day per 1000 square feet of floor area.

\subsection{Parking generation compared with trip generation}

To test the reliability of parking and trip generation rates, we can compare the number of vehicle trips per day to fast-food restaurants with the peak parking demand at fast-food restaurants. The number of daily round trips to a site divided by the number of parking spaces at the site can be interpreted as the parking turnover rate, which is the number of different cars that occupy a parking space during the day. Table 1 shows both the trip generation rates (expressed in round trips, or half the number of trip ends) and parking generation rates per 1000 square feet of floor area for all the land uses that are common between the Trip Generation and Parking Generation editions published in 1987 (the most recent edition of Parking Generation).

The final column of Table 1 shows the parking turnover rate. For example, on an average weekday a fast-food restaurant generates 316.1 vehicle-round-trips and a peak parking occupancy of 10 spaces per 1000 square feet of floor area. Therefore, 32 different cars occupy each parking space during an average day (316.1/10).

Table 1

Trip generation rates compared with parking generation rates (per 1000 square feet)

\begin{tabular}{lccc}
\hline Land use & $\begin{array}{c}\text { Trip generation rate } \\
\text { (round trips/day) }\end{array}$ & $\begin{array}{c}\text { Parking generation rate } \\
\text { (parking spaces) }\end{array}$ & $\begin{array}{c}\text { Trips per parking space per } \\
\text { day (round trips/space) }\end{array}$ \\
\hline Manufacturing & 1.9 & 1.6 & 1.2 \\
Furniture store & 2.2 & 1.2 & 1.8 \\
Industrial park & 3.5 & 1.5 & 2.4 \\
Residential condominium & 2.9 & 1.1 & 2.6 \\
Quality restaurant & 47.8 & 12.5 & 3.8 \\
Warehousing & 2.4 & 0.5 & 4.9 \\
Motel & 5.1 & 0.9 & 5.7 \\
Retirement community & 1.7 & 0.3 & 6.1 \\
Church & 3.8 & 0.4 & 9.0 \\
Government office & 34.5 & 3.8 & 9.0 \\
Discount store & 35.6 & 3.6 & 10.0 \\
Hardware store & 25.6 & 2.4 & 10.6 \\
Supermarket & 62.8 & 2.9 & 21.9 \\
Tennis courts/club & 16.5 & 0.7 & 23.2 \\
Fast food w/ drive-thru & 316.1 & 10.0 & 31.6 \\
Fast food w/o drive-thru & 388.6 & 11.7 & 33.3 \\
Bank w/ drive-in & 145.6 & 4.2 & 34.4 \\
Bank w/ walk-in only & 95.0 & 0.6 & 150.8 \\
Convenience market & 443.5 & 1.4 & 314.6 \\
\hline
\end{tabular}

Sources: Institute of Transportation Engineers (1987a, b). 
The parking turnover rate at furniture stores is only 1.8 cars per parking space per day, implying slow business. At churches it is a busy nine cars per space per day, heralding a religious awakening. At government office buildings it is also nine cars per space per day, suggesting that the state has not withered away. At tennis courts it is 23.2 cars per space per day, implying very short games but many of them.

These turnover rates are unreliable because the underlying parking and trip generation rates are often based on scant evidence (the parking or trip generation rate is based on only one survey for 4 of the 19 land uses). The surveys of parking generation for each land use were probably conducted at different sites and at different times from the surveys of trip generation. These bizarre turnover rates also suggest a more serious problem: the parking and trip generation rates are misleading guides to transportation and land use planning.

\subsection{The tail that wags two dogs}

Free parking is an unstated assumption behind both parking generation rates and minimum parking requirements. Transportation engineers do not consider the price of parking as a variable in estimating parking generation rates. Urban planners who set parking requirements make the same mistake. Urban planners interpret the ITE parking generation rates as the demand for parking, neglecting the fact that demand has been observed only where parking is free. The following five steps describe the dysfunctional interaction between transportation engineers and urban planners.

1. Transportation engineers survey parking occupancy at sites that offer ample free parking and lack public transit. The ITE summarizes the peak parking occupancies observed at each land use and reports the parking generation rate.

2. Urban planners use the parking generation rates to set minimum parking requirements for all land uses. Because the required parking supply is so large, the market price of parking is zero, and most new developments offer free parking.

3. Transportation engineers survey vehicle trips to and from sites that offer free parking. The ITE summarizes the data on vehicle trips observed at each land use and reports the trip generation rate.

4. Transportation planners design the roads and highways to satisfy the trip generation rates. Therefore, the transportation system provides enough capacity to satisfy the expected demand for vehicle trips to and from land uses that provide free parking.

5. Urban planners limit land use density so that new development will not generate more vehicle trips than nearby roads and highways can carry.

In this five-step process, the unstated assumption of free parking underpins planning for both transportation and land use. Peak parking occupancy observed at sites that offer free parking becomes the minimum number of parking spaces that all development must provide. Ubiquitous free parking then stimulates the demand for vehicle travel. The observed travel demand becomes the guide for designing the transportation system that brings cars to the free parking. Planners limit development density to prevent traffic congestion around the sites that offer free parking. 
Because of this circular reasoning, free parking is the tail that wags two dogs - transportation and land use.

\section{The cost of complying with minimum parking requirements}

Theory and data play small roles in setting parking requirements, and so we should not be surprised that the requirements often look foolish. This foolishness is a serious problem because minimum parking requirements increase development cost and they powerfully shape land use, transportation, and urban form. While urban planners rarely consider the cost of parking requirements, developers rarely have the luxury of not considering this cost.

\subsection{The cost of parking spaces}

What does it cost a developer to comply with minimum parking requirements? We can estimate this cost by taking into account the number of required parking spaces and the cost per space. Appendix A presents evidence that aboveground structured parking often costs about US $\$ 10,000$ per space and that underground parking often costs about US $\$ 25,000$ per space. The most common parking requirement for an office building is four spaces per 1000 square feet of floor area. $^{6}$ If aboveground parking costs US\$10,000 per space, the cost of providing the required parking is US\$40 per square foot of floor area $(4 \times \mathrm{US} \$ 10,000 / 1000)$. If underground parking costs US $\$ 25,000$ per space, the cost of the required parking is US\$100 per square foot of floor area $(4 \times \mathrm{US} \$ 25,000 / 1000)$.

In Los Angeles the average construction cost of an office building, excluding the cost of parking, is about US\$150 per square foot. ${ }^{7}$ Therefore, in this example, the cost of four aboveground parking spaces per 1000 square feet of office space increases the cost of the office space by $27 \%$ (US\$40/150). The cost of four underground parking spaces per 1000 square feet of office space increases the cost of the office space by $67 \%$ (US\$100/150).

Because motorists park free for most vehicle trips, they clearly do not pay the cost of providing parking spaces. If motorists do not pay for parking spaces, who does? Minimum parking requirements bundle the cost of parking spaces into the cost of development, and thereby increase the cost of all the goods and services sold at the sites that offer free parking. These requirements "externalize" the cost of parking, so that you cannot reduce what you pay for parking by con-

\footnotetext{
${ }^{6}$ Two surveys of parking requirements in 117 cities in Southern California suggest that the typical parking requirement for office buildings is 4 spaces per 1000 square feet of floor area. The first survey was conducted in 1975 , and it was repeated for the same cities in 1993 (Shoup, 1995). In both years the most frequent parking requirement (the mode) was 4 spaces per 1000 square feet of floor area. Sixty-five percent of the cities that required less than the mode in 1975 had increased their requirement by 1993, and none had reduced it. Eighty percent of the cities that required more than the mode in 1975 had reduced their requirement by 1993, and none had increased it. These changes doubled the percentage of cities requiring 4 spaces per 1000 square feet from $27 \%$ in 1975 to $54 \%$ in 1993 .

7 The average cost of US\$150 per square foot refers to Class A, steel-framed office buildings. This figure includes construction cost, tenant improvement costs, and "soft" costs such as financing, insurance, and real estate taxes during construction, but excludes the cost of parking. This figure was supplied by the Los Angeles County Assessor.
} 
suming less of it. Minimum parking requirements bypass the price system in the markets for both transportation and land.

\subsection{The cost of parking spaces compared with the cost of cars}

Minimum parking requirements increase the supply and reduce the price - but not the cost - of parking. To reveal the size of the resulting subsidy for parking, we can compare the value of parking and cars with what motorists pay for parking and cars.

Table 2 shows the number of registered vehicles and the capital value (in current dollars) of these vehicles for the years 1985-1995. ${ }^{8}$ For example, 202 million vehicles were registered in 1995, and this stock of vehicles was valued at US\$1079 billion, or US\$5352 per vehicle. ${ }^{9}$ How does this value of vehicles compare with the value of parking spaces?

Minimum parking requirements are intended to satisfy the expected peak demand for parking at every land use - at home, work, school, banks, restaurants, shopping centers, movie theaters, and hundreds of other land uses from airports to zoos. Because the peak parking demands at different land uses occur at different times of the day or week, and may last for only a short time, several off-street parking spaces must be available for every motor vehicle. Although no one knows the number of parking spaces per car, Gruen (1973) estimated that for every car there must be at least one parking space at the place of residence and three to four spaces elsewhere.

Suppose there are four parking spaces per vehicle. If the average vehicle is worth US\$5352 and if there are four parking spaces per vehicle, the average vehicle value per parking space is US\$1338 (US\$5352/4). Therefore, if the average land-and-improvement value of a parking space exceeds US\$1338, the average value of four parking spaces exceeds the average US\$5352 value per vehicle they serve. Because US\$1338 is a very modest sum for both the land and construction cost of a parking space, the total value of all parking spaces probably exceeds the total value of all vehicles.

Motorists pay for their vehicles (worth US\$1.1 trillion in 1995) but they park free for 99\% of automobile trips. ${ }^{10}$ Motorists pay so little for parking because parking requirements bundle the cost of parking into the cost of development. Parking is free for most automobile trips only because its cost has been shifted in to higher prices for everything else. Everyone pays for parking whether they use it or not. Cars have many external costs, but the cost of parking in cities may be

\footnotetext{
${ }^{8}$ The US Department of Commerce has estimated the total value of all fixed reproducible tangible wealth in the United States for the years 1929-1995. One category of this wealth is the capital value of all vehicles (cars and trucks). The capital value of an asset in each year is defined as the cumulative value of past gross investment in that asset minus the cumulative value of past depreciation.

${ }^{9}$ Because $65 \%$ of all vehicles were more than five years old in 1995, depreciation explains the low average value of US\$5352 per vehicle.

${ }^{10}$ The total receipts of all private and public parking operators in the United States was only US\$4.4 billion in 1992. Private operators received $83 \%$ of this revenue, and municipalities received $17 \%$. The 1992 Census Data on Service Industries reports the revenue for private parking facilities, and the 1992 Census of Governments reports revenue from municipal parking facilities. Parking operators receive revenue that motorists do not pay when someone else pays it for them-as with validated and employer-paid parking. On the other hand, the Census data do not include the parking receipts of establishments primarily engaged in activities other than parking (department stores, hospitals, and restaurants, for example). If these two factors cancel each other, motorists paid about US\$4.4 billion for parking in 1992.
} 
Table 2

The value of motor vehicles in the United States

\begin{tabular}{llll}
\hline Year & $\begin{array}{l}\text { Registered vehicles } \\
\text { (million) }\end{array}$ & \multicolumn{2}{l}{ Capital value of vechicles } \\
\cline { 3 - 4 } & & Total (US\$ billion) & Per Vehicle (US\$/vehicle) \\
\hline 1985 & 172 & 614 & 3575 \\
1986 & 176 & 688 & 3918 \\
1987 & 179 & 731 & 4085 \\
1988 & 184 & 790 & 4286 \\
1989 & 187 & 833 & 4446 \\
1990 & 189 & 868 & 4595 \\
1991 & 188 & 879 & 4673 \\
1992 & 190 & 910 & 4778 \\
1993 & 194 & 961 & 4952 \\
1994 & 198 & 1032 & 5211 \\
1995 & 202 & 1079 & 5352 \\
\hline
\end{tabular}

Sources: Katz and Herman (1997) for capital values and Federal Highway Administration (1995) for number of vehicles. Values are expressed in current dollars of each year.

far greater than all these other external costs combined. By hiding a huge share of the cost of owning and using cars in cities, minimum parking requirements intensify all the other problems of external cost (such as air pollution and traffic congestion), making an already bad situation far worse.

Minimum parking requirements distort transportation and land use. They are not, however, the first example of an unwise professional practice that has produced unintended consequences. A medical analogy illustrates the problem.

\section{An analogy: lead poisoning}

Parking requirements in urban planning resemble lead therapy in medicine. Lead has antiseptic properties because it is toxic to microorganisms, and until the 20th century physicians prescribed lead to treat many ailments. One popular medical treatise recommended using lead as a therapy for abscesses, burns, cancer, contusions, gout, gunshot wounds, inflammation, itch, piles, rheumatism, ruptures, sprains, stiffness of the joints, and ulcers. ${ }^{11}$

Early physicians did not realize that lead is toxic to humans, and lead poisoning went largely unnoticed as a medical problem until the end of the nineteenth century. Nevertheless, a few early critics had recognized lead's harmful effects. As a printer, Benjamin Franklin had much contact with lead, and he wrote to a friend in 1786, "The Opinion of this mischievous effect from lead is at least above sixty year old; and you will observe with Concern how long a useful Truth may be known and exist, before it is generally receiv'd and practis'd on."12

\footnotetext{
${ }^{11}$ Goulard (1784), p. 2) says, "when the reader has perused the following treatise he will be inclined to think that this metal [lead] is one of the most efficacious remedies for the cure of most diseases which require the assistance of surgery".

${ }^{12}$ Quoted in McCord (1953), p. 398).
} 
Lead continued to be used as medicine for more than a century after Franklin's warning, and folk remedies continue to use it as an ingredient today. Lead has local antiseptic properties, but any local benefit comes at a high price to the whole person.

\subsection{Minimum parking requirements: urban lead therapy}

Like lead therapy, minimum parking requirements produce a local benefit - they ensure that every land use can accommodate all the cars "drawn to the site". But this local benefit comes at a high price to the whole city. Minimum parking requirements increase the density of both parking spaces and cars. More cars create more traffic congestion, which in turn provokes calls for more local remedies, such as street widening, intersection flaring, intelligent highways, and higher parking requirements. More cars also produce more exhaust emissions (which until recently included lead). Like lead therapy, minimum parking requirements produce a local benefit but damage the whole system.

Minimum parking requirements resemble other primitive medical practices that were adopted without good theory and careful empirical research. Describing a leading medical text written in 1896, Lewis Thomas (1981), p. 40) says.

The public expectation then, as now, was that the doctor would do something. There was no disease for which a treatment was not recommended... Every other page contains a new, complex treatment always recommended with the admonition that the procedure be learned by rote (since it rarely made any intrinsic sense) and be performed precisely as described. Acute poliomyelitis had to be treated by subcutaneous injections of strychnine; the application of leeches; the administration of belladonna, extract of ergot, potassium of iodide, and purgative doses of mercury; the layering of thick ointments containing mercury and iodine over the affected limbs; faradic stimulation of the muscles; ice-cold shower baths over the spine; and cupping... each of these with a dosage schedule to be followed precisely, some of them singly, others in various combinations... All of this has the appearance of institutionalized folly, the piecing together of a huge structure of nonsensical and dangerous therapy, and indeed it was. The pieces were thought up and put together almost like thin air, but perhaps not quite. Empiricism made a small contribution, just enough in the case of each to launch it into fashion.

I suspect that, looking backward a century from now, urban planners will see minimum parking requirements to have been no better than physicians now see lead therapy: a poison prescribed as a cure. Like many discredited and abandoned medical practices, minimum parking requirements are A "institutionalized folly".

Many parking spaces are provided voluntarily rather than in response to requirements. And far from being a poison, parking is an indispensable part of the transportation system. What is poisonous, is for planners to require massive overdoses of parking.

Sometimes a disaster must occur to stimulate the reexamination of customary practices. Minimum parking requirements have produced no single disaster, but evidence of their harm confronts us everywhere - traffic congestion, air pollution, energy imports, the orientation of the built environment around the car, perhaps even global climate change. Although not their sole cause, minimum parking requirements magnify all these problems. 
Likening parking requirements to lead poisoning is a criticism of current planning practice, not of individual planners. Physicians who prescribed lead were making an honest mistake. Urban planners who prescribe parking requirements are, I believe, also making an honest mistake. Although many planners may agree with this criticism, they may also feel that it is unhelpful unless the critic can propose a better way to deal with the parking problem. I will propose an alternative: cities should price on-street parking rather than require off-street parking.

\section{An alternative: let prices do the planning}

Minimum parking requirements are a mistake but they do respond to a real problem - spillover parking. If a land use does not provide enough off-street parking, some motorists drawn to the site will park on nearby streets, competing for the scarce curb parking supply. Urban planners know that this spillover parking creates enormous political problems. If spillover parking from a new development congests the adjacent curb parking, everyone nearby will angrily ask planners and politicians, "How could you let this happen"?

To prevent parking spillover where adjacent curb parking is free, new land uses must provide enough off-street spaces to satisfy the demand for free parking. Free curb parking explains why planners consciously or unconsciously base off-street parking requirements on the demand for free parking. In his survey of planning directors in 144 cities, Richard Willson (1996) asked "Why does your city have minimum parking requirements"? The most frequent response was the circular explanation "to have an adequate number of spaces". In effect, planners treat free parking as an entitlement, and they consider the resulting demand for free parking to be a "need" they can measure.

Because parking requirements are so ingrained in planning practice, complaining about them may seem futile, like complaining about photosynthesis or gravity. If free parking were an entitlement and the planner's goal were to prevent parking spillover, requiring enough off-street parking to meet the demand at zero price would make sense. But free parking is not an entitlement. As the alternative to requiring off-street parking, consider pricing curb parking.

\subsection{The market price for curb parking}

The market price for curb parking is the price that matches demand with supply and keeps a few spaces vacant. Traffic engineers usually recommend a vacancy rate for curb parking of at least $15 \%$ to ensure easy parking access and egress. ${ }^{13}$ If cities priced curb parking to balance supply and demand with a few vacant spaces on every block, motorists could always find a convenient parking space close to their final destination.

Fig. 4 illustrates the policy of market prices for curb parking. Because the supply of curb spaces is fixed, the supply of curb spaces available with a $15 \%$ vacancy rate is a vertical line positioned above the horizontal axis at an $85 \%$ occupancy rate. The demand curve slopes downward, and the market-clearing price of parking occurs where the demand curve intersects the vertical supply

\footnotetext{
${ }^{13}$ See Brierly (1972), May (1975) and Witheford and Kanaan (1972).
} 


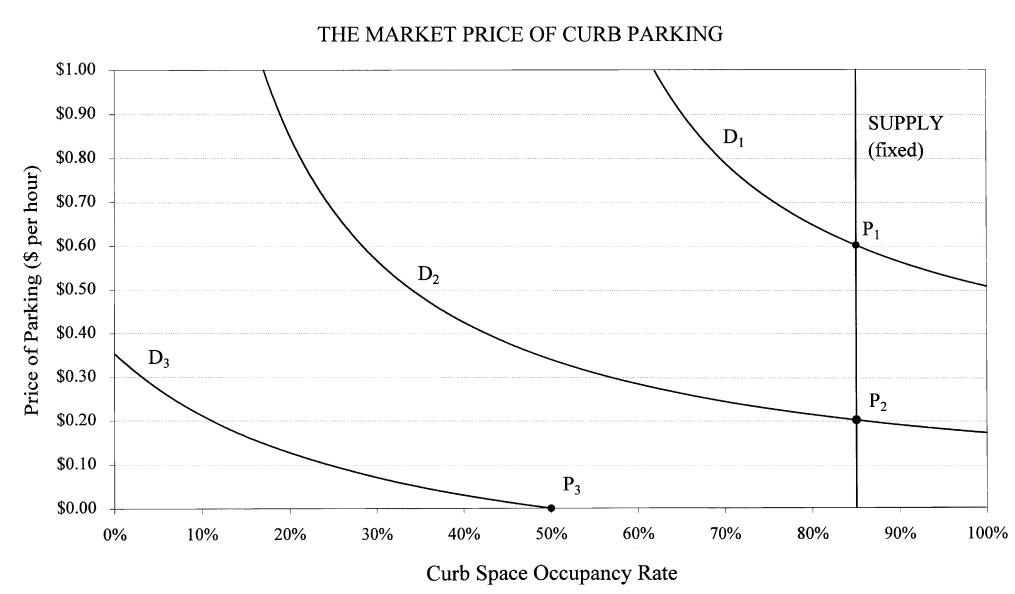

Fig. 4. The market price of curb parking.

curve. For example, when parking demand is high (demand curve $\mathrm{D}_{1}$ ), the price that will yield a $15 \%$ vacancy rate is high $\left(\mathrm{P}_{1}\right.$ is $\left.60 \mathrm{~d} / \mathrm{h}\right)$. When demand is lower (demand curve $\left.\mathrm{D}_{2}\right)$, a price of only $20 \% / \mathrm{h}$ will yield a $15 \%$ vacancy rate. When parking demand is lowest (demand curve $\mathrm{D}_{3}$ ), the vacancy rate will be $50 \%$ even when parking is free.

If the price of parking is set too high, many parking spaces remain vacant, and a valuable resource is unused. If the price of parking is set too low, the occupancy rate reaches $100 \%$, and motorists hunting for a vacant space waste time, congest traffic, and pollute the air. Because the demand for parking rises and falls during the day but the supply of parking is fixed, demandresponsive parking prices would necessarily rise and fall to maintain an "inventory" of vacant parking spaces on each block. The lowest price that will yield a vacancy rate of about $15 \%$ is the market price of curb parking.

Obviously, prices cannot constantly fluctuate to maintain a vacancy rate of exactly $15 \%$, but they can vary sufficiently to avoid chronic over- or under-occupancy. Commercial parking operators always set prices high enough to avoid regularly putting out the "full" sign, and cities could contract with commercial operators to price curb parking properly, if necessary.

\subsection{Parking benefit districts}

Elsewhere I have argued that market prices can effectively regulate the off-street parking supply, and that the government's chief contribution should be to set market prices for curb parking. I have also argued that, to make this pricing solution politically popular, cities could establish Parking Benefit Districts that dedicate curb parking revenue to pay for public services in the neighborhood where the revenue is collected. ${ }^{14}$ If the benefits financed by parking charges were visible and local, residents would want to charge market prices for curb parking for the revenue,

\footnotetext{
${ }^{14}$ See Shoup $(1992,1994,1995,1997)$ for the proposal to use the revenue from market-priced curb parking to finance neighborhood public services. Several new technologies can charge for curb parking without using conventional parking meters. Cities have also begun to subcontract with private enterprises to collect curb parking revenue.
} 
not because they thought it good public policy. Residents who benefit from parking charges paid by strangers would begin to think like parking lot owners.

The economic argument to charge for curb parking is efficiency - the benefits would outweigh the costs. The political argument to create Parking Benefit Districts is distribution - the benefits for neighborhoods would lead residents to vote for the proposal. Parking meters have few friends if their revenue disappears into the city's general fund. Curb parking revenue needs the appropriate recipient - its neighborhood - before residents will recommend market prices for parking. For example, parking revenue could pay to plant street trees, repair sidewalks, or put utility wires underground. Curb parking charges would yield more revenue than the property taxes in many neighborhoods, so many residents could reap enormous benefits. Charging strangers to park in front of your house is like Monty Python's scheme for Britain to tax foreigners living abroad.

Charging for parking does not require a meter at every space. Several payment systems - from high-tech electronic in-vehicle meters and multispace meters to low-tech paper stickers - have eliminated the practical and aesthetic objections to charging for parking. Where the potential revenues are high and the collection costs are low, the transaction costs of charging for parking are not a serious objection. The problem is political, not technical, and dedicating curb parking revenue to its neighborhood can solve the political problem.

\section{A model of parking choice}

If market prices allocated parking spaces, how would motorists decide where to park? A simple model of parking choice will help to answer this question. To anticipate the results, market prices will allocate the most convenient parking spaces to motorists who: (a) carpool, (b) park for a short time, (c) walk slowly, and (d) place a high value on reducing walking time. Conversely, market prices will allocate the peripheral parking spaces to motorists who: (a) drive alone, (b) park for a long time, (c) walk fast, and (d) place a low value on reducing walking time.

\subsection{Variables in the model of parking choice}

Suppose the price of parking is highest at the destinations where parking demand is highest, and that the price declines with distance from these destinations. Since the price of parking increases as you drive toward your destination, you will pay more money to park closer to your destination but you will also spend less time walking from your car to your destination. Given the trade-off between money spent on parking and time spent on walking, where should you park your car and walk the rest of the way?

To find the optimal parking space, consider the following variables (and their dimensions): $d$ is the distance from parking space to final destination (miles), $p(d)$ is the price of parking at distance $d$ from the final destination (US\$/hour), $t$ is the parking duration (hours), $w$ is the walking speed from parking space to final destination (miles/hour), $n$ is the number of persons in the car (persons) and $v$ is the average value of time spent walking ( $\$ /$ hour/person).

The total cost associated with parking at any location is the money cost of parking plus the time cost of walking from the parking space to the final destination and back. The money cost of 
parking equals the parking duration multiplied by the price per hour, or $t p(d) .{ }^{15}$ The time to walk from the parking space to the final destination and back is $2 d / w$, the distance walked divided by the walking speed. To convert this time cost of walking into its money equivalent we can multiply the walking time by the dollar value of time, $v$. Because everyone in the car, $n$, experiences this time cost, the (monetized) cost of time spent walking equals $2 n v d / w .{ }^{16}$ At distance $d$ from the final destination the total cost of parking and walking is therefore

$$
t p(d)+2 n v d / w \text {. }
$$

The first term of the expression is the money cost of parking, and the second term is the (monetized) time cost of walking from the parking space to the final destination and back.

\subsection{The optimal parking space}

What parking location minimizes the total cost of parking and walking? As you drive toward your destination the cost of parking increases and the cost of walking decreases. The minimum total cost of parking and walking occurs where the increase in the money cost of parking balances the decrease in the time cost of walking. If the money cost of parking increases less than the time cost of walking decreases as you approach your destination, you should keep driving. If the money cost of parking increases more than the time cost of walking decreases, you have driven too far. ${ }^{17}$

Differentiating equation (1) with respect to $d$ and setting the result equal to zero gives the distance from a final destination that minimizes the total cost of parking and walking.

$$
t \partial p / \partial d+2 n v / w=0 \text { and }-t \partial p / \partial d=2 n v / w .
$$

The changes in the money cost of parking $(t \partial p / \partial d)$ and the time cost of walking $(2 n v / w)$ are equal in value and opposite in sign for any small movement from the location that minimizes the total cost of parking and walking. A parking space substantially closer to your final destination will increase the money cost of parking by more than it reduces the time cost of walking. A parking space substantially farther from your destination will increase the time cost of walking by more than it reduces the money cost of parking. The optimal parking space perfectly balances greed and sloth.

\footnotetext{
${ }^{15}$ I assume that you know how long you want to park. Alternatively, you may know only the expected value of how long you want to park. In either case, you pay only for the exact time that you park. The parking charge is a linear function of the number of minutes you park, with no advance commitment to how long you will park.

${ }^{16}$ The value of time is the price you are willing to pay to reduce the time spent walking between your parking space and your final destination. It will depend on whether you are in a hurry, how tired you are, packages you are carrying, the weather, and many other circumstances that can vary greatly from trip to trip.

${ }^{17}$ This parking location model resembles the Alonso-Mills-Muth housing location model. Muth (1969), p. 22) explains that the equilibrium housing location is where "the reduction in expenditure necessary to purchase a given quantity of housing that results from moving a unit distance away from the market (equals) the increase in transport costs occasioned by such a move". If we substitute the words "parking" for "housing" and "walking" for "transport" in this extract, Muth is describing the equilibrium parking location. The quantity of space occupied is variable in the housing decision but fixed in the parking decision, while the time that space is occupied is fixed in the housing decision but variable in the parking decision.
} 


\subsection{An example}

Suppose the price of parking is US\$1/h at your destination, and that the price declines with distance from your destination according to the negative exponential formula

$$
p(d)=\$ 1 \mathrm{e}^{-2 d} \text {. }
$$

Eq. (3) implies that the price of parking, $p$, declines with distance, $d$, from the center, and that the slope of the curve relating price to distance also declines with increasing distance from the center (see Fig. 5). A negative exponential curve is typical of the relationship between commercial parking prices and the distance from activity centers.

Suppose that you want to park for $4 \mathrm{~h}(t=4)$, you are alone $(n=1)$, your time is worth US $\$ 8 / \mathrm{h}$ $(v=\mathrm{US} \$ 8)$, and you walk 4 miles an hour $(w=4)$. Fig. 5 shows the cost of parking and of walking as a function of parking $d$ miles from your destination. The money cost of parking $4 \mathrm{~h}$ is US $\$ 4 \mathrm{e}^{-2 d}$, which declines with distance from your destination. ${ }^{18}$ The time cost of walking is $(2 \times 1 \times \mathrm{US} \$ 8 / 4) d$, which increases with distance from your destination. The total cost of parking and walking (the upper curve in Fig. 5) reaches its minimum value of US\$3.35 at a distance somewhere between 0.3 and 0.4 miles from your destination. To minimize the total cost of parking and walking you should park about a third of a mile from your destination and walk the rest of the way. ${ }^{19}$

Solving Eq. (2) gives the exact distance that minimizes the total cost of parking and walking. Substituting Eq. (3) into Eq. (2) and solving for the optimal distance from a final destination, denoted as $d^{*}$, gives

$$
d^{*}=\left[-\log _{e}(n v / t w)\right] / 2 .
$$

Given the values of $n=1$ person, $v=\mathrm{US} \$ 8 \mathrm{~h}, t=4 \mathrm{~h}$ and $w=4$ miles an hour, the value for $d^{*}$ in Eq. (4) is 0.34 miles. At this distance the price of parking is $50 \mathrm{~d} / \mathrm{h}$, so the cost of parking four hours is US\$2. Walking the round trip of 0.68 miles from parking space to final destination and back at four miles an hour will take about $10 \mathrm{~min}$. If time costs US $\$ 8 / \mathrm{h}, 10 \mathrm{~min}$ will cost US\$1.35. The minimum total cost of parking and walking to your destination is thus US\$3.35 for the trip (see Fig. 5). ${ }^{20}$

\footnotetext{
${ }^{18}$ The exponential relationship implies that the parking price gradient gets steeper as you approach your destination (the absolute value of $\partial p / \partial d$ increases as $d$ approaches 0 ).

${ }^{19}$ Automobile speed and operating cost have been neglected but are easily added to the model. Parking closer to your destination increases driving time and automobile operating cost. Therefore, the total time-and-money cost of driving, parking, and walking is minimized where the total value of driving and walking time saved by parking closer equals the total parking and automobile operating cost added by parking closer. If $a$ denotes automobile operating cost (US\$/ mile), and $s$ denotes driving speed (miles/hour), total cost is minimized where $t(\partial p / \partial d)=-2 n v(1 / w-1 / s)+2 a$. If $a$ is low and $s$ is high, they are negligible parts of the decision, and the solution for $d^{*}$ reduces to Eq. (4).

${ }^{20}$ If you want to spend $4 \mathrm{~h}$ at your destination, the $10 \mathrm{~min}$ walking time must be added to the time at your destination, so the total parking duration will be $4 \mathrm{~h}$ and $10 \mathrm{~min}$. The additional parking duration will add another $8.54 \phi$ to the parking cost. This result suggest that you should park a bit closer to your destination when you consider the effect of walking time on the total parking cost. To simplify the discussion, this factor has been neglected. A negative value of $d^{*}$ implies that you should park at your destination.
} 
THE COST OF PARKING AND WALKING

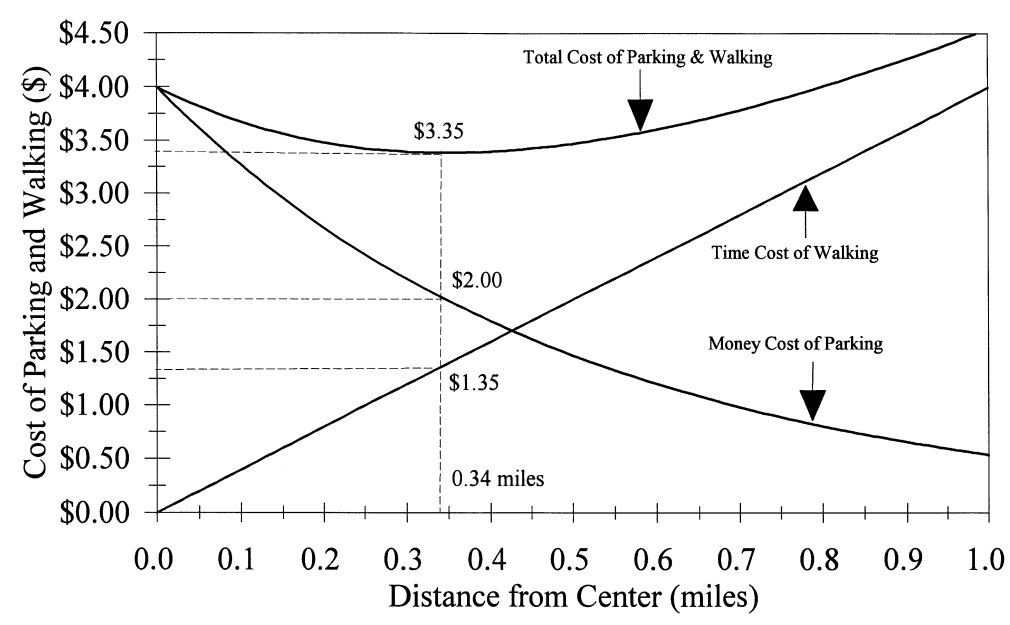

Assumptions: $t=4$ hours, $n=1$ person, $v=\$ 8$ per hour, $w=4$ miles per hour, $p(d)=\$ 1 e^{-2 d}$

Fig. 5. The cost of parking and walking.

The total money-and-time cost curve is flat between 0.25 and 0.5 miles from the destination because the slopes of the money-parking-cost and monetized-time-cost curves are about equal in absolute value but opposite in sign within this range. ${ }^{21}$ The total cost of parking and walking is about US\$3.35 anywhere between 0.25 and 0.5 miles from your destination. Parking less than 0.25 miles or more than 0.5 miles from your destination increases the total cost of parking and walking. For example, the total cost of parking and walking is US\$4 both at your destination and also at 0.8 miles from your destination.

\subsection{Implications of the model}

Motorists do not use calculus when choosing where to park. The proposed parking location model merely expresses in mathematical form some of the various factors that motorists surely consider when they pay to park. The model confirms common sense, but several of its predictions are not immediately obvious.

First, the number of persons in a car is as important as the value of their time in determining parking location. For example, a carpool of four people who each value time at US\$5/h $(n v=4 \times 5)$ will choose the same location as a solo driver who values time at US\$20/h

\footnotetext{
${ }^{21}$ The monetized time cost of walking from your parking space to your destination and back increases with distance from your destination at a constant rate of US $\$ 4$ per mile. The money cost of parking decreases with distance from your destination at a rate of US\$4 per mile at 0.34 miles from your destination. At parking locations closer than 0.34 miles from your destination, the money cost of parking decreases with increasing distance from your destination at a rate of more than US\$4 per mile. At parking locations farther than 0.34 miles from your destination, the money cost of parking decreases with increasing distance from your destination at a rate of less than US\$4 per mile.
} 
Table 3

Elasticity of $d^{*}$ with respect to parking choice variables

\begin{tabular}{lll}
\hline Variable & Partial derivative of $d^{*}$ & Elasticity of $d^{*}$ with respect to variable $i$ \\
$t$ (parking duration) & $\partial d^{*} / \partial t=+1 /(2 t)>0$ & $\epsilon_{t}=+1 /\left(2 d^{*}\right)>0$ \\
$w$ (walking speed) & $\partial d^{*} / \partial_{\mathrm{w}}=+1 /(2 w)>0$ & $\epsilon_{w}=+1 /\left(2 d^{*}\right)>0$ \\
$n$ (number of persons) & $\partial d^{*} / \partial n=-1 /(2 n)<0$ & $\epsilon_{n}=-1 /\left(2 d^{*}\right)<0$ \\
$v$ (value of time) & $\partial d^{*} / \partial v=-1 /(2 v)<0$ & $\epsilon_{v}=-1 /\left(2 \mathrm{~d}^{*}\right)<0$ \\
\hline
\end{tabular}

Note: $d^{*}=\left[-\log _{e}(n v / t w)\right] / 2$ and $\epsilon_{i}=\left(\partial d^{*} / \partial i\right) /\left(d^{*} / i\right)$.

$(n v=1 \times 20)$, all else equal. A higher vehicle occupancy and a higher value of time justify parking closer to the final destination.

Second, parking duration is as important as the value of time in determining parking location. For example, a solo driver who values time at US $\$ 10 / \mathrm{h}$ and parks for one hour $(v / t=10 / 1)$ will choose the same location as another solo driver who values time at US\$20/h and parks for two hours $(v / t=20 / 2)$, all else equal. A shorter parking duration justifies parking closer to the final destination.

Third, the number of persons in a car is as important as parking duration in determining parking location. For example, a solo driver who parks for $1 \mathrm{~h}(n / t=1 / 1)$ will choose the same location as a three-person carpool who park for $3 \mathrm{~h}(n / t=3 / 3)$, all else equal.

Table 3 shows the derivatives and elasticities of the optimal distance, $d^{*}$, with respect to the variables that determine it. The derivative of $d^{*}$ is positive with respect to $t$ and $w$, which implies that the longer you park and the faster you walk, the farther away you should park. The derivative of $d^{*}$ is negative with respect to $n$ and $v$, which implies that the more people in your car and the higher value of their time, the closer in you should park.

The elasticities of $d^{*}$ with respect to the variables that determine it decrease with increasing distance from the center (see Fig. 6). For example, the elasticity of $d^{*}$ with respect to the parking duration, $t$, is $+1 /\left(2 d^{*}\right)$. At $d^{*}=0.25$ miles from the center, the elasticity of $d^{*}$ with respect to $t$ is +2 , so a $10 \%$ decrease in the length of time you want to park will shift your optimal parking location $20 \%$ closer to your final destination. 22

These predictions are consistent with previous research on parking choices. David Gillen (1978) developed a model of parking location choice similar to the one expressed in Eq. (4), although he did not consider the number of persons in a car. Using data from Toronto, Gillen found that motorists who pay for parking by the hour are willing to trade a shorter parking duration for a closer parking location.

Using trip data from Vancouver, Brown and Lambe (1972) showed that allocating parking spaces by market prices will minimize the total walking time from parking spaces to final destinations. A linear programming model that minimizes total walking time predicted commercial offstreet parking prices with an average error of only $20 \%$. The price of curb parking was well below the level that would minimize total walking time.

\footnotetext{
${ }^{22}$ This result follows from the assumed functional relationship between $p$ and $d$. In this particular case, the same relative increase in $t, w, n$, or $v$ will always produce the same absolute change in $d^{*}$. As $d^{*}$ approaches zero, the elasticities approach infinity.
} 


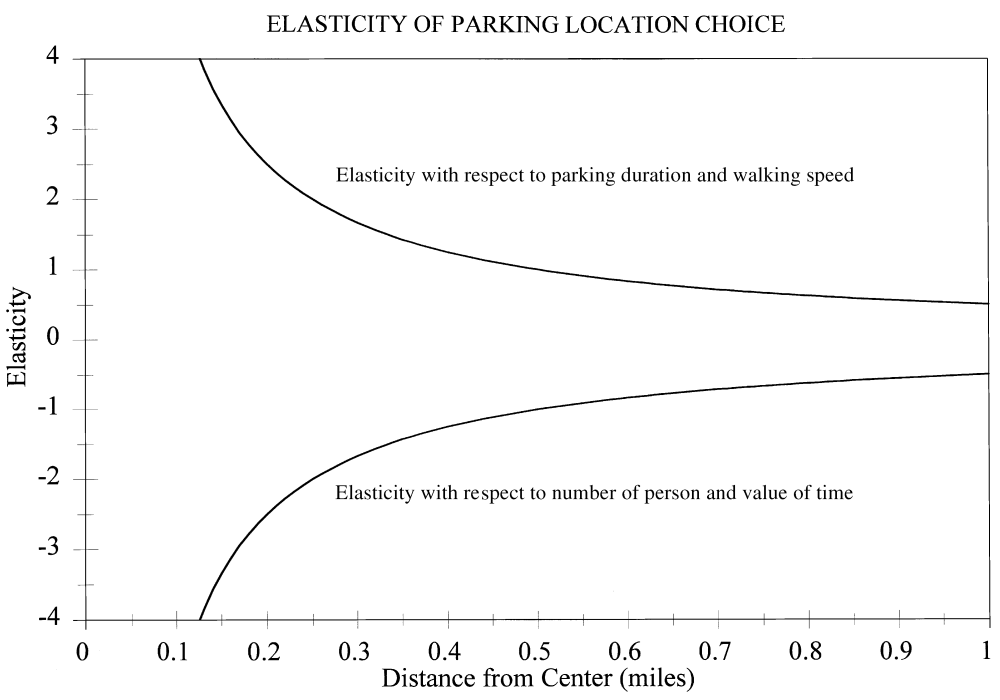

Fig. 6. Elasticity of parking location choice.

Naturally, a simple model of parking prices like the one presented here does not describe most current parking decisions because parking is free for $99 \%$ of all automobile trips. The model is a simplified description of parking choice, but its assumptions are far more sensible than the assumptions behind minimum parking requirements. ${ }^{23}$

\section{Efficiency and equity of charging for curb parking}

If curb parking were priced to yield a minimum vacancy rate of about $15 \%$ in every location, the resulting price gradients would shift predictably throughout the day as demand shifts. The peak parking prices might occur at employment centers during the day, at entertainment centers during the evening, and in high-density residential areas during the night. Many overlapping price gradients would form a three-dimensional parking price surface whose height at any point is the vertical summation of all the individual gradients. The individual gradients would form around many dispersed centers, like anthills covering a terrain that itself has peaks (the central business districts) and valleys (low density neighborhoods). The price of parking at any location would rise

\footnotetext{
${ }^{23}$ Several relevant variables and interactions between variables have also been left out of the model. For example, parking closer to your destination incurs additional driving time and automobile expense. How long you want to park depends on the price of parking because you can reduce the parking cost by staying a shorter time at your final destination. How long you want to park also depends on how much time you spend walking because the parking duration is the sum of the time at the final destination and the time walking to and from it. A further complication is that the value of time spent driving can be different from the value of time spent walking.
} 
and fall during the day, and the local peaks would shift around like kittens fighting under a blanket.

\subsection{Efficiency}

Market prices would allocate parking spaces among motorists in a logical way. The more convenient parking spaces would go to carpoolers, those in a hurry, those who want to park for only a short time, those who have difficulty walking, and those more willing to spend money. The best parking spaces could always be reserved for those with physical disabilities. The more distant parking spaces would go to solo drivers, those with time to spare, those who want to park a long time, those who enjoy walking, and those more eager to save money.

Even if market prices can efficiently allocate a fixed stock of parking spaces, can market forces alone supply enough spaces to meet the demand for parking? If minimum parking requirements are eliminated, the ratio of parking spaces to cars will decline, and the price of parking will rise. This price rise will have two effects on demand and supply.

First, motorists will economize on parking by changing their travel behavior. Shifting to higher occupancy vehicles to spread the cost of parking among more people will reduce the demand for parking. Shifting to walking, cycling, or public transit will also reduce the demand for parking. Shifting vehicle trips to off-peak will reduce the demand for parking at peak hours. Finally, citizens can choose to own fewer cars, and this will reduce the demand for parking.

Second, freed from minimum parking requirements, developers will supply parking spaces in response to parking prices. The higher price of parking will encourage developers to voluntarily supply more parking in places where the resulting revenue will cover the cost of providing the parking. Parking will tend to become unbundled from other transactions, and firms that specialize in providing parking will manage more of the parking supply. Off-street parking prices will tend to cover the cost of providing parking spaces, including the cost of land, and these off-street prices will put a ceiling on the price of adjacent curb parking.

Flexible market prices can equate demand with the fixed supply of parking in the short run, and these prices will signal where the supply can profitably be increased in the long run. The proper role for the government is to price curb parking to maintain a minimum vacancy rate so that parking will always be available if motorists are willing to pay for it.

Market prices for parking resemble a spot market for land. Demand-responsive parking prices would reveal what parking spaces are really worth, and how motorists are willing to change their travel choices to save money on parking. Motorists could choose parking spaces according to how long they want to stay, how many people are in the car, how they value walking time (are they in a hurry? are they carrying heavy packages? are they tired? are they short of money?) and many other circumstances of time and place that only the individual motorists can know.

In contrast to the "spontaneous" order created by market prices and individual choices, urban planners require almost every land use to provide at least enough parking spaces to satisfy the peak demand for free parking. As a result, parking is free for almost every automobile trip because the cost of parking is shifted into higher prices for almost everything else. Minimum parking requirements in zoning ordinances are a disastrous substitute for millions of individual evaluations of what a parking space is worth. 


\subsection{Equity}

The proposal to price curb parking rather than require off-street parking raises a serious political question. Is it fair to charge motorists for parking? To judge whether charging for parking is fair, it must be compared with the alternative-minimum parking requirements. Minimum parking requirements force everyone to pay for parking through higher prices for all other goods and services, but everyone does not benefit equally from free parking. ${ }^{24}$ On average, households with incomes below US\$10,000 a year own only one car, while households with incomes above US $\$ 40,000$ a year own 2.3 cars. Eight percent of non-Hispanic White households, 19\% of Hispanic households, and 30\% of African-American households do not own a car. In total, 10.6 million American households do not own a car, yet even these households indirectly pay the costs imposed by minimum parking requirements. ${ }^{25}$ Because cars are not distributed equally in the population, charging motorists only for the parking they use is fairer than requiring everyone to pay for parking whether they use it or not.

Market prices would not allocate the best parking spaces only to the rich. With market prices, motorists can pay less for parking if they carpool, stay for a shorter time, or park farther away, and they will pay nothing for parking if they walk, bicycle or ride public transit. Even those who cannot regularly afford to park in the best spaces can park in them on occasions when time is very important. Because income is only one factor that determines the value of time on a particular trip, and because the value of time is only one factor that determines parking location, income is only one of many factors that determine parking location.

Given the eternal debate on the merits of markets versus planning, many skeptics will distrust using prices to allocate parking spaces. But even those who doubt the ability of markets to allocate resources fairly may agree that relying on prices to allocate curb parking spaces and using the revenue to fund public services will contribute to a host of social, economic, and environmental goals they support.

\section{Conclusion: time for a paradigm shift}

Although it would be presumptuous to call urban planning a science, minimum parking requirements in planning resemble a paradigm in science. According to Thomas Kuhn (1996), a paradigm is a conceptual scheme that has gained universal acceptance throughout a profession, and each profession's practices embody its ruling paradigms.

Kuhn argued that scientific education inculcates in students an intense commitment to the existing scientific paradigms. But planning education ignores parking requirements, and therefore does not inculcate in students any commitment to them. Instead, motorists have come to expect the free parking that the requirements produce. The planning profession's commitment to parking requirements is based not on education and science but on motorists' yearning to park free.

\footnotetext{
${ }^{24}$ Shoup (1997) explains how parking requirements increase the price of housing, and Willson (1995) explains how they increase the price of office space.

${ }^{25}$ The 1990 NPTS reports the distribution of vehicle ownership by household income (Pisarski, 1995, pp. 3-24). The 1990 Census reports the distribution of households that do not own a car (Pisarski, 1996, p. 36).
} 
Discussing the difficulty of paradigm shifts in science, Kuhn asks, "How can a conceptual scheme that one generation admiringly describes as subtle, flexible, and complex become for a later generation merely obscure, ambiguous, and cumbersome"'? ${ }^{26}$ Without doubt, minimum parking requirements are obscure, ambiguous, and cumbersome. In addition, minimum parking requirements impose enormous hidden costs, and they impede our progress toward important social, economic, and environmental goals. Planning for parking deserves a new paradigm.

Minimum parking requirements are based on two highly unreasonable assumptions: (1) the demand for parking does not depend on its price, and (2) the supply of parking should not depend on its cost. This neglect of price and cost stems from a belief that planners can assess community needs and can regulate the land market to meet these needs. Regulation is justified in many cases where market prices fail to communicate social costs. But market failure does not justify minimum parking requirements.

Letting prices determine the number of parking spaces will transfer to the market an important function that urban planners now perform. But this does not mean an end to planning for parking because planners should regulate many other features of parking that affect the community, such as aesthetics, landscaping, layout, location, pedestrian access, provisions for the handicapped, setback, signage, and stormwater runoff.

Pricing curb parking rather than requiring off-street parking will improve urban design, reduce traffic congestion, restrain urban sprawl, conserve natural resources, and produce neighborhood public revenue. Eliminating parking requirements will also reduce the cost of housing and of many other goods and services. In conclusion, deregulating the quantity and increasing the quality of parking will improve transportation, land use, and the environment.

\section{Acknowledgements}

I am grateful to the Federal Transit Administration and the University of California Transportation Center for financial support. For their many suggestions for improving this paper I am also grateful to Ellison Alegre, Lee Burns, Jeffrey Brown, Eric Carlson, Joy Chen, Elke Daugherty, D. Gregg Doyle, David Gillen, Daniel Hess, Eugene Kim, Kristen Massey, Andrew Mondschein, Virginia Parks, John Pucher, Thomas Rice, Gian-Claudia Sciara, Patricia Shoup, Seth Stark, Richard Willson, and Matthew Zisman.

\section{Appendix A. The cost of parking spaces}

How much does a parking space cost? This question has no easy answer because the cost of parking depends on the value of land, which varies greatly among sites. But in the case of structured parking we can account for the value of land as its opportunity cost for surface parking. The number of spaces a parking structure adds to the parking supply is the number of

\footnotetext{
${ }^{26}$ Kuhn (1957), p. 76) was describing how latter-day astronomers looked back at the Ptolemaic, earth-centered concept of the universe.
} 
parking spaces in the structure minus the number of surface parking spaces lost as a result of building the structure. The structure's construction cost (excluding land value) divided by the number of parking spaces added to the parking supply gives the structure's cost per parking space added, which accounts for land value as the opportunity cost of the surface parking spaces lost (Shoup, 1997).

This methodology was used to calculate the construction cost per parking space added by twelve parking structures built on the UCLA campus between 1961 and 1991. ${ }^{27}$ Each structure's original cost was converted into dollars of 1998 purchasing power by adjusting for construction cost inflation since the structure was built.

The average cost of the six structures built in the 1960s was US\$13,400 per space added, while the average cost of the six structures built since 1977 was US\$25,600 per space added. The newer parking structures are more expensive because they are smaller and partly or entirely underground, compared with the larger, aboveground structures built earlier. That is, the type of parking structure-not an increase in the real cost of parking spaces (above the rate of inflation of general construction costs)-can explain the higher real cost of new parking spaces.

We can test this hypothesis that the type of parking structure explains the increase in cost after 1977. Since the initial study of the twelve structures built between 1961 and 1991, UCLA has built two new campus parking structures as additions to existing parking structures. The first is a 1995 aboveground addition to the aboveground structure built in 1964 . The second is a 1998 underground addition to the underground structure built in 1983. Table 4 compares the cost per parking space added by the two original structures and their subsequent additions. The ENR Construction Cost Index is used to convert the original construction costs to 1998 dollars.

The cost was US\$12,214 per space for the original aboveground structure built in 1964, and US $\$ 14,725$ per space for the addition built 31 yr later. ${ }^{28}$ The cost was US\$28,540 per space for the original underground structure built in 1983, and US\$26,300 per space for the addition built $15 \mathrm{yr}$ later. $^{29}$ The close match between the cost of each original parking structure and the cost of its later

\footnotetext{
${ }^{27}$ See Shoup (1997) for the details of the cost per parking space added by the twelve parking structures. The 20-city average of the ENR Construction Cost Index for 31 March 1998, was divided by the average ENR Construction Cost Index for the year in which the parking structure was built. This ratio was then multiplied by the original construction cost to yield the construction cost expressed in dollars of 1998 purchasing power.

${ }^{28}$ The original aboveground structure contains 39\% more parking spaces than the aboveground addition, and its footprint is twice as large as that of the addition. Economies of scale help to explain the original structure's lower cost per space. The UCLA parking structures built in the 1960s look like the aboveground parking structures built in suburban areas where vacant land is abundant. In case studies of suburban office developments in Southern California in 1994, Willson (1995), p. 39) found "the average combined land and construction cost for structure parking in the case study sites was US\$12,300 per space". This cost is almost identical to the average cost of US\$12,400 (in 1994\$) per parking space added by the aboveground parking structures built at UCLA in the 1960s.

${ }_{29}$ The underground addition is almost three times the size of the original underground structure, and economies of scale help to explain the newer structure's lower cost per space. The UCLA parking structures built since 1977 are typical of the parking structures built in dense areas where vacant land is scarce. The higher cost of recent parking structures at UCLA thus reflects the higher cost of building parking structures in dense urban areas.
} 
Table 4

Cost of aboveground and underground parking spaces (cost per space added by parking structures in Los Angeles)

\begin{tabular}{|c|c|c|c|c|c|}
\hline & \multicolumn{2}{|c|}{ Aboveground (UCLA) } & \multicolumn{2}{|c|}{ Underground (UCLA) } & \multirow{2}{*}{$\begin{array}{l}\text { Underground (Pershing Square) } \\
1950 \text { Structure }\end{array}$} \\
\hline & 1964 Structure & 1995 Addition & 1983 Structure & 1998 Addition & \\
\hline Current US\$ & 1946 & 13,712 & 19,752 & 26,300 & 2500 \\
\hline 1998 US\$ & 12,214 & 14,725 & 28,540 & 26,300 & 28,800 \\
\hline
\end{tabular}

The original portion of Structure 3, built in 1964, contains 1168 spaces in five aboveground levels; the addition built in 1995 contains, 840 spaces in seven aboveground levels. The original portion of Structure 4, built in 1983, contains 448 spaces in two underground levels; the addition built in 1998 contains 1263 spaces in two underground levels. The Pershing Square Garage in downtown Los Angeles contains 2150 spaces in three underground levels. The ENR Construction Cost Index is used to convert original construction costs to 1998 values.

addition suggests that, after correcting for inflation, the cost of building parking structures has changed little in recent decades.

To test this finding of cost stability, Table 4 also shows the cost of an underground garage constructed beneath Pershing Square in downtown Los Angeles in $1952 .{ }^{30}$ When the original cost of US\$2500 per space is converted to its equivalent in 1998 purchasing power, the cost of the Pershing Square garage is US\$25,700 per parking space, very close to the cost of the two underground garages built at UCLA in 1983 and 1998. In real terms, the cost of building underground parking has not changed in half a century.

If these high costs are surprising, it is only because the cost of parking is rarely calculated. Nevertheless, there is other evidence about cost because some cities allow developers to pay a fee in lieu of providing required parking spaces. To justify the in-lieu fees, some of these cities carefully document their cost of providing public parking spaces. ${ }^{31}$ In Palo Alto, California, the cost is US $\$ 17,848$ per space added by a municipal parking structure. In Lake Forest, Illinois, the cost is US\$18,000 per space for the land and construction cost of surface parking lots. In Walnut Creek, California, the cost is US $\$ 32,400$ per space added by a municipal parking structure. In Beverly Hills, California, the average cost was US\$37,000 per space for the estimated land and construction cost of municipal parking structures. The cost of parking spaces at UCLA is thus in line with the cost of parking spaces in cities that allow developers to pay inlieu fees.

The cost of many surface parking spaces is less than the cost of structured parking spaces, but land values understate the cost of surface parking because developers who are required to provide parking spaces will bid less for land. Therefore, the market value of land subject to a minimum parking requirement will understate the cost of surface parking spaces. For example, when Oakland, California, introduced its parking requirement of one space per 1000 square feet for apartment buildings, land values fell by 33\% (Shoup, 1997). Willson (1995) estimated that increasing the parking requirement for office buildings in Southern California by 1.3 spaces per 1000

\footnotetext{
${ }^{30}$ Klose (1965), p. 190) gives the original cost of constructing the Pershing Square garage.

${ }^{31}$ See Shoup, forthcoming. These costs refer to the values that were used to justify the cities' in-lieu fees in 1996. In Beverly Hills the cost refers to the average estimated land and construction cost of municipal parking spaces for projects that applied to pay the in-lieu fees between 1978 and 1992; the highest cost was US\$53,000 per parking space.
} 
square feet would reduce land values by $32 \%$. Because minimum parking requirements depress land values, low land values do not necessarily imply that minimum parking requirements have a low cost.

\section{References}

Brierly, J., 1972. Parking of Motor Vehicles, 2nd ed. Applied Science Publishers, London.

Brown, S.A., Lambe, T.A., 1972. Parking prices in the central business district. Socio-Economic Planning Sciences 6, 133-144.

Chapin, F.S., 1957. Urban Land Use Planning. Harper and Brothers, New York.

Chapin, F.S., 1965. Urban Land Use Planning, 2nd ed. University of Illinois Press, Urbana, IL.

Chapin, F.S., Kaiser, E., 1979. Urban Land Use Planning, 3rd ed. University of Illinois Press, Urbana, IL.

Dickey, J., 1983. Metropolitan Transportation Planning, 2nd ed. McGraw Hill, New York.

Federal Highway Administration, 1995. Highway statistics summary to 1995, taken from www.bts.gov/site/news/fhwa/ HighwayStats-Summary95/section2.html. Office of Highway Information Management.

Gillen, D., 1978. Parking policy, parking location decisions and the distribution of congestion. Transportation 7, 69-85.

Goulard, T., 1784. A Treatise on the Effects and Various Preparations of Lead: Particularly of the Extract of Saturn, for Different Chirurgical Disorders. Elmsley in the Strand, London.

Gruen, V., 1973. Centers for the Urban Environment: Survival of the Cities. Van Nostrand Reinhold, New York.

Hanson, S. (Ed.), 1995. The Geography of Urban Transportation. Guilford Press, New York.

Institute of Transportation Engineers, 1987a. Parking Generation, Institute of Transportation Engineers, 2nd ed. Washington, DC.

Institute of Transportation Engineers, 1987b. Trip Generation, Institute of Transportation Engineers, 4th ed. Washington, DC.

Kaiser, E., Godschalk, D., Chapin, F.S., 1995. Urban Land Use Planning, 4th ed. University of Illinois Press, Urbana, IL.

Katz, A., Herman, S., 1997. Improved estimates of fixed reproducible tangible wealth, 1929-1995. Survey of Current Business, May 1997.

Klose, D., 1965. Multi-story and Underground Garages (Parkhäuser und Tiefgaragen). Verlag Gerd Hartje, Stuttgart.

Kuhn, T., 1957. The Copernican Revolution. Harvard University Press, Cambridge, MA.

Kuhn, T., 1996. The Structure of Scientific Revolutions, 3rd ed. University of Chicago Press, Chicago.

May, A.D., 1975. Parking control: experience and problems in London. Traffic Engineering and Control.

McCord, C., 1953. Lead and lead poisoning in early America. Industrial Medicine and Surgery 22 (9), 393-399.

Meyer, M., Miller, E., 1984. Urban Transportation Planning. McGraw Hill, New York.

Muth, R., 1969. Cities and Housing. University of Chicago Press, Chicago.

Papacostas, C., Prevedouros, P., 1993. Transportation Engineering and Planning, 2nd ed. Prentice Hall, Englewood Cliffs, NJ.

Pisarski, A., 1995. The demography of the U.S. vehicle fleet: observations from the NPTS. 1990 Nationwide Personal Transportation Survey, Special Reports on Trip and Vehicle Attributes, US Department of Transportation. Washington, DC.

Pisarski, A., 1996. Commuting in America II: The Second National Report on Commuting Patterns and Trends. Eno Transportation Foundation, Landsdowne, VA.

Planning Advisory Service, 1971. An Approach to Determining Parking Demand, Planning Service Report Number 270. American Planning Association, Chicago.

Planning Advisory Service, 1991. Off-Street Parking Requirements: A National Review of Standards, Planning Advisory Service Report Number 432. American Planning Association, Chicago.

Shoup, D.C., 1992. Cashing Out Employer-Paid Parking. US Department of Transportation, Washington, DC, p. 156. Shoup, D.C., 1994. Cashing in on curb parking. Access 4, $20-26$.

Shoup, D.C., 1995. An opportunity to reduce minimum parking requirements. Journal of the American Planning Association 61 (1), 14-28. 
Shoup, D.C., 1997. The high cost of free parking. Journal of Planning Education and Research. 17 (1), 1-18.

Shoup, D.C., 1999. In-lieu of required parking. Journal of Planning Education and Research 18 (4) forthcoming. 1999.

Thomas, L., 1981. Medicine without science. The Atlantic Monthly, pp. 40-42.

Willson, R., 1995. Suburban parking requirements: a tacit policy for automobile use and sprawl. Journal of the American Planning Association 61 (1), 29-42.

Willson, R., 1996. Local jurisdiction parking requirements: a survey of policies and attitudes. Working Paper, Department of Urban and Regional Planning, California State Polytechnic University, Pomona, California.

Witheford, D.K., Kanaan, G.E., 1972. Zoning, Parking, and Traffic. Eno Foundation for Transportation, Westport, CT. 